Research article

\title{
Management impacts on fire occurrence: A comparison of fire regimes of African and South American tropical savannas in different protected
} areas

\author{
Swanni T. Alvarado a, b, *, Thiago Sanna Freire Silva a, Sally Archibald ${ }^{\text {b }}$

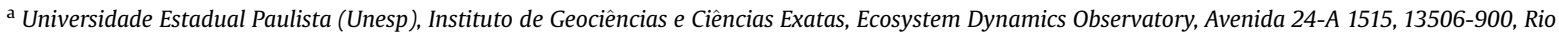 \\ Claro, Brazil \\ ${ }^{\mathrm{b}}$ Centre for African Ecology, School of Animal, Plant and Environmental Sciences, University of the Witwatersrand, Johannesburg, Private Bag X3, WITS, \\ 2050, South Africa
}

\section{A R T I C L E I N F O}

\section{Article history:}

Received 11 July 2017

Received in revised form

30 March 2018

Accepted 1 April 2018

Available online 14 April 2018

\section{Keywords:}

Burned area

Burn scar size distribution

Fire regime

Fire return period

Management intervention

Number of ignitions

Seasonal fire distribution

\begin{abstract}
A B S T R A C T
Humans can alter fire dynamics in grassland systems by changing fire frequency, fire seasonality and fuel conditions. These changes have effects on vegetation structure and recovery, species composition, and ecosystem function. Understanding how human management can affect fire regimes is vital to detect potential changes in the resilience of plant communities, and to predict vegetation responses to human interventions. We evaluated the fire regimes of two recently protected areas in Madagascar (Ibity and Itremo NPA) and one in Brazil (Serra do Cipó NP) before and after livestock exclusion and fire suppression policies. We compare the pre- and post-management fire history in these areas and analyze differences in terms of total annual burned area, density of ignitions, burn scar size distribution, fire return period and seasonal fire distribution. More than $90 \%$ of total park areas were burned at least once during the studied period, for all parks. We observed a significant reduction in the number of ignitions for Ibity NPA and Serra do Cipó NP after livestock exclusion and active fire suppression, but no significant change in total burned area for each protected area. We also observed a seasonal shift in burning, with fires happening later in the fire season (October-November) after management intervention. However, the protected areas in Madagascar had shorter fire return intervals (3.23 and 1.82 years) than those in Brazil (7.91 years). Our results demonstrate that fire exclusion is unattainable, and probably unwarranted in tropical grassland conservation areas, but show how human intervention in fire and vegetation patterns can alter various aspects of the fire regimes. This information can help with formulating realistic and effective fire management policies in these valuable conservation areas.
\end{abstract}

(c) 2018 Elsevier Ltd. All rights reserved.

\section{Introduction}

Fire is a natural disturbance that determines the structure of vegetation in tropical savannas (Bond et al., 2005). Fire regimes are mainly driven by climate, but can change over time in response to human activities (Archibald et al., 2012; Hoffmann et al., 2012). People can alter the dynamics of fire directly, by changing the number and timing of ignitions or by suppressing fires, and indirectly by altering the climate and thus affecting fuel amount and vegetation connectivity (Archibald, 2016; Bowman et al., 2011).

\footnotetext{
* Corresponding author. Present address: Universidade Estadual Paulista (Unesp), Instituto de Geociências e Ciências Exatas, Ecosystem Dynamics Observatory, Caixa postal 178, Avenida 24-A 1515, 13506-900, Rio Claro, SP, Brazil.

E-mail address: swanni_ta@yahoo.es (S.T. Alvarado).
}

Past analyses of direct human impacts on fire regimes have shown a reduction in fire size, changes in the timing of peak fire occurrences and an increase in the length of the fire season (Archibald, 2016; Hantson et al., 2015; Le Page et al., 2010), with important implications on fire intensity and tree-grass dynamics.

Humans have historically used fire to support several livelihood activities, such as renewing grasses for pasture, or cleaning and preparing agricultural fields (Miranda et al., 2009). People have also used fire as a management tool for conservation and restoration on fire-prone ecosystems (Andersen et al., 1998; Baker and Shinneman, 2004), and fire has been used as a tool to protest against the government (Kull, 2002a). In grassy ecosystems, fire is sometimes used by protected area managers to control woody cover and maintain open vegetation (Higgins et al., 2007), to 
conserve biodiversity or to attract wildlife for tourism. Prescribed fires can also be used to control fire intensity and size to avoid the occurrence of large and severe fires, which are significantly harder to control and may have catastrophic consequences (Price et al., 2015).

Despite the recognized importance of fire in grasslands, fire is still a controversial issue in many countries, having in many cases its use forbidden by local legislation (Durigan and Ratter, 2016; Kull, 2000). In these countries, fire is considered as a destructive disturbance and an extended fire suppression policy is often established, but the effects of this management strategy on vegetation and on natural fire regimes is still poorly known. In African savannas, where fire is banned or illegal, late season fires seem to be more common (Archibald, 2016; Laris and Wardell, 2006), which can be hotter and more intense, spreading faster than early season fires and burning a larger amount of accumulated dry biomass over larger areas (Govender et al., 2006; Miranda et al., 2009).

In protected areas, fire regimes may be changed by management interventions, leading to changes in vegetation structure and recovery, species composition and ecosystem function (Van Wilgen et al., 2004). Quantifying changes in fire regimes can thus help assess the consequences of various management decisions (Moritz et al., 2009) and help ecologists and land managers to better predict vegetation responses to climatic and anthropogenic changes. Fire regimes are commonly quantified by total area burned and time elapsed since the last fire, variables that respond to climatic variability and human activities (Alvarado et al., 2017; Archibald et al., 2010). Another metric, fire return period, describes the expected average time between fires, and determines long-term regrowth ability and potential fuel accumulation (Moritz et al., 2009; Polakow and Dunne, 1999). Changes in fire return periods can have strong ecological impacts, as the life cycles of different species are adapted to particular fire-free intervals. Also, the distribution of burned area sizes can be an ecological indicator related to overall fire impact on ecosystems, and can change due to human activities (Hantson et al., 2015).

We evaluated changes in fire regimes caused by management interventions, using as comparative case-studies the Serra do Cipó National Park (Brazil) and the Ibity and Itremo New Protected Areas (Madagascar). Despite biogeographic and political differences between the continents, these parks have very similar environmental conditions, and have been subject to similar local and national fire suppression policies, banning the use of prescribed fires and excluding livestock as most fires there are ignited for pasture management (Mistry et al., 2005). The comparison of protected areas located on different continents but sharing environmental and management contexts, particularly fire suppression policies and livestock exclusion to reduce or eliminate antropic fires, allows us to provide robust information to support the management and application of fire in Africa and South America, in areas with no formal fire management which so far have only excluded fire as a measure to improve conservation efforts.

We thus compared the pre- and post-management fire history in these parks, to answer the following questions: 1) How similar were the fire regimes between protected areas before and after management intervention? 2) What changes occurred in fire regimes after livestock and fire suppression interventions were implemented? 3) Which characteristics of the fire regime were most affected by management interventions?

\section{Methods}

\subsection{Study sites}

We compared the fire regimes of two protected areas in
Madagascar and one protected area in Brazil. Ibity $\left(47^{\circ} 01^{\prime} \mathrm{E}\right.$, $20^{\circ} 07^{\prime} \mathrm{S}$ ) and Itremo $\left(46^{\circ} 38^{\prime} \mathrm{E}, 20^{\circ} 35^{\prime} \mathrm{S}\right)$ New Protected Areas (NPAs) are located in Madagascar's central highlands; Ibity NPA is located $200 \mathrm{~km}$ southwest of the capital (Antananarivo), and Itremo NPA is located $200 \mathrm{~km}$ southwest of Ibity (Fig. 1). The Serra do Cipó National Park (SCNP) $\left(43^{\circ} 30^{\prime} \mathrm{W}, 19^{\circ} 20^{\prime} \mathrm{S}\right)$ is located in the southern portion of the Espinhaço mountain range, about $100 \mathrm{~km}$ northeast of Belo Horizonte, Minas Gerais, Brazil (Fig. 1). The park is encircled by the Morro da Pedreira Environmental Protection Area (MP-EPA), which provides a buffer zone to the protected ecosystems within the park (França and Ribeiro, 2008).

The two regions share many ecological similarities: climate is markedly seasonal, warm subtropical with dry winters and hot summers; soils are quartzitic, and vegetation is mainly composed by altitudinal savannas interspersed with rocky outcrops (Birkinshaw et al., 2006, 2004; Negreiros et al., 2011) (See Appendix S1 for more details). Vegetation in all sites is hyperdiverse and dominated by herbaceous species, with a high rate of endemism (Alvarado et al., 2014; Le Stradic et al., 2014). Despite having different evolutionary histories of herbivory, the traditional uses of savannas and the origins of natural and anthropic disturbances are similar for both continents, where livestock grazing is the dominant herbivory pressure (Alvarado et al., 2015; Le Stradic et al., 2014).

\subsection{Park management histories}

In Madagascar, the creation process of both NPAs started in 2003, led by the Missouri Botanical Garden (MBG) for Ibity (Alvarado et al., 2015) and by the Kew Madagascar Conservation Center (KMCC) for Itremo (KEW, 2012), who have since been in charge of the conservation and management of these areas. In Brazil, the SCNP was created in 1984, while the MP-EPA was created in 1990 as a protected buffer area (França and Ribeiro, 2008). The management of these areas is currently the responsibility of the Brazilian Institute for Biodiversity Conservation (ICMBio).

In both countries, fire has long been considered by local government and some conservationist and managers as a "threat" to vegetation, and strong fire suppression policies have been implemented in the management plan of these protected areas. In Ibity and Itremo, human presence has been completely excluded. Strong agricultural and livestock pressures are still observed in the surrounding areas of Ibity, where population has been estimated at about 89 inhabitants $/ \mathrm{km}^{2}$, while Itremo remains mostly isolated, with ca. 5 inhabitants $/ \mathrm{km}^{2}$ (Birkinshaw et al., 2006, 2004). At Itremo, most of the population lives on the eastern side of the protected area, and the western side is almost completely unpopulated (Birkinshaw et al., 2004). The application of local community laws (known as dina) is common on both protected areas and include early fire detection and fire suppression (Alvarado et al., 2015). At the SCNP, human activity and occupation have also been excluded upon park establishment, but human activities are still allowed within the surrounding MP-EPA area, with a density of ca. 50 inhabitants $/ \mathrm{km}^{2}$ in rural areas, and ranging from ca. 50 to more than 500 inhabitants $/ \mathrm{km}^{2}$ in urban areas (IBGE, 2010).

The main source of ignition in all parks has been attributed to escaped anthropogenic fires, as local people intentionally use burning to renew pasture or clear fields (Alvarado et al., 2015; Kull, 2002b; Mistry, 1998; Mistry et al., 2005). Natural causes have been reported as an important source of ignition for other areas in Brazil, mainly by lightning during the transition between dry and wet seasons (Ramos-Neto and Pivello, 2000), but there is no information on the ratio of human to natural caused fires for any of the studied areas. We expect fires observed within the parks to have been naturally caused by lightning or set by humans (accidentally 


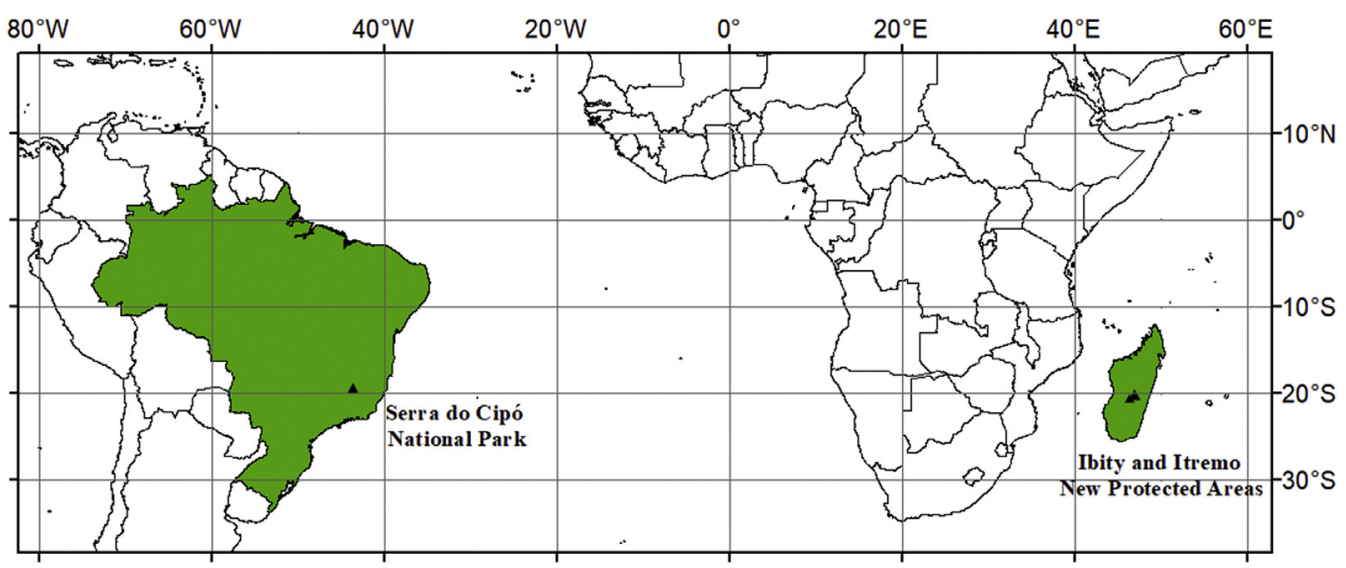

Fig. 1. Location of the study areas: Serra do Cipó National Park (state of Minas Gerais, Brazil) and Ibity and Itremo New Protected Areas (District of Antsirabe, Madagascar).

or arson) within the buffer area and then spread into the park.

\subsection{Study design}

Management intervention measures seeking conservation in the studied parks included the progressive reduction of livestock herding, starting in 2002 and culminating with livestock free status in 2003 for Madagascar and 2008 for Brazil (França and Ribeiro, 2008), and the creation of local fire brigades to actively suppress fires. However, livestock ranching and human fire practices are still active in the areas surrounding the parks. Thus, to evaluate the impact of human activities, we contrasted fire regimes along two axes: before and after fire management interventions (time), and between park limits and surrounding "buffer" areas where human activities are still allowed (space).

For the temporal component, we separated the data in pre- and post-introduction of management interventions; for Madagascar, we contrasted 1989-2003 ( $\mathrm{n}=15$ years) with $2004-2015(\mathrm{n}=12$ years), while for Brazil we compared 1984-2002 ( $\mathrm{n}=19$ years) against 2003-2015 ( $n=13$ years). For the spatial component, we contrasted fire regimes in Ibity $\left(59.7 \mathrm{~km}^{2}\right)$ with a $3-\mathrm{km}$ wide buffer zone $\left(137.9 \mathrm{~km}^{2}\right)$, and regimes in the $\operatorname{SCNP}\left(338 \mathrm{~km}^{2}\right)$ were compared with the existing MP-EPA buffer zone, varying between 7 and $31 \mathrm{~km}$ wide $\left(1001.1 \mathrm{~km}^{2}\right)$. For Itremo $\left(360.6 \mathrm{~km}^{2}\right)$, we did not include a buffer zone given its remoteness and very low population density (Birkinshaw et al., 2004) (Appendix S1).

\subsection{Remote sensing data}

Fire mapping was based on the existing record of Landsat (TM, $\mathrm{ETM}+$ and OLI) images, available at the Earth Explorer database of the United States Geological Service (USGS, earthexplorer.org). The study area in Brazil corresponds to path 218/row 73, and both Malagasy study sites are included on path 159/row 74, in the WRS-2 Landsat reference system.

The fire season for the Brazilian sites occurs between July and November, with a peak of fires between September and October (Alvarado et al., 2017). The fire season for the Malagasy sites occurs between June and November, with a peak of fires in September. Both periods correspond to the dry seasons of each continent. All available images acquired during the fire seasons of 1984-2015 were downloaded, but images between 1984 and 1988 were unavailable for Madagascar. This resulted in between 4 and 13 usable scenes per year due to varying cloud cover. For Brazil, we updated the Serra do Cipó maps produced by Alvarado et al. (2017) for the period $1984-2014$ by including the available images in 2015 . We obtained all images as Higher-Level Collection-1 data products (www.earthexplorer.org), which are corrected for geometric and atmospheric effects, and include a cloud cover mask (Zhu et al., 2015). All spatial data was produced and analyzed using the Universal Transverse Mercator projection (zone 23S for Brazil and 38S for Madagascar), and the WGS-84 reference datum.

\subsection{Reconstructing fire occurrence}

Mapping the extent of burned areas in the two parks in Madagascar was achieved using the methods described in Alvarado et al. (2017). Contrast controlled false color composites were created for each image, using bands 5 (1550-1750 nm), 4 $(760-900 \mathrm{~nm})$, and $3(630-690 \mathrm{~nm})$ of the TM and ETM + sensors, and bands $6(1570-1650 \mathrm{~nm}), 5(850-880 \mathrm{~nm})$ and 4 $(640-670 \mathrm{~nm})$ of the OLI sensor. We then performed visual interpretation of each false color composite, followed by manual delineation of burned areas in vector format.

Mapping produced datasets with the location, area, and date of each observed burn scar (accurate to within a few months) over 27 years for Madagascar and 32 years for Brazil. We then aggregated vector maps by year and converted the results into a time series of binary raster maps of annual burned area. We then used the individually mapped burn scars and the consolidated annual burned area maps to derive several fire regime metrics (Table 1 ).

\subsection{Data analysis}

We ran Wilcoxon-tests to identify changes in fire regime metrics (density of ignitions, total burned area, and mean and maximum size of burn scars) between pre- and post-management intervention (Crawley, 2011). Homogeneity of variance was confirmed with the Bartlett test (Crawley, 2011). All analyses were carried out using R software version R2.3.0 (R Core Team, 2016).

\section{Results}

Our reconstruction of fire history in Malagasy protected areas between 1989 and 2015 revealed that $59.2 \mathrm{~km}^{2}$ ( $\left.\sim 99 \%\right)$ of park area were burned in Ibity NPA, 119.9 (87\%) $\mathrm{km}^{2}$ were burned within the buffered zone around Ibity, and $348.5 \mathrm{~km}^{2}$ (96.6\%) were burned within Itremo NPA. For Brazil, between 1984 and $2015286.7 \mathrm{~km}^{2}$ (91\%) were burned within the SCNP, and $714.9(71 \%) \mathrm{km}^{2}$ within the buffered area MP-EPA. We found high inter-annual variation in the percentage of burned area in all parks, except Itremo, where a large percentage of the area is burned every year (Appendix S2.1). More 
than $90 \%$ of the entire area of all parks was burned at least once during the studied period.

Fire count: The comparison between Malagasy and Brazilian protected areas shows lower fire counts in Brazil, with few areas burned more than 15 times (Fig. 2a, b, c). Itremo had higher fire counts on the west side of the massif, while Ibity had higher fire counts at the edges of the protected area (Fig. 2a and b). Itremo had a much more uniform temporal distribution of fire counts than the other two parks - both having most of their areas burned less than 10 times over the study period (Appendix S2.2). For Ibity and its buffer, respectively, $21 \%$ and $28 \%$ of all burned areas were burned between one and four times, $48 \%$ and $35 \%$ between five and nine times, and 30\% and 24\% ten times or more, from 1989 to 2015 (Appendix S2.2). In contrast, for Itremo $20 \%$ of all burned area was burned between one and four times, $20 \%$ between five and nine times, and $57 \%$ ten times or more (Appendix S2.2). For the SCNP and MP-EPA, respectively, $55 \%$ and $49 \%$ of all burned areas were burned between one and four times, $33 \%$ and $20 \%$ between five and nine times, and $2 \%$ and $3 \%$ ten times or more, from 1984 to 2015 (Appendix S2.2).

Time since last fire: In Madagascar more than three quarters of the studied areas were burned within the past four years (78\% and $72 \%$ for Ibity and Itremo, respectively), with less areas spread among longer times since last burning (Fig. $2 \mathrm{~d}$ and e, Appendix S2.3). Less than $5 \%$ was last burned between 16 and 27 years ago (1.5\% and $2.8 \%$ respectively). For the buffer area around Ibity we observed that half of the study area was last burned between 1 and 4 years ago (58\%) and only 16\% was last burned between 16 and 27 years ago (Appendix S2.3). For Brazilian parks, we observed that a lower percent of the studied area was burned within the past four years for the SCNP and MP-EPA (45\% and 32\% respectively), with less than a quarter burned between 16 and 32 years ago (24\% and $17 \%$ respectively) (Appendix S2.3).

Density of ignitions, total burned area and fire scar size: We observed a significant reduction in the density of ignitions for Ibity, the SCNP and its buffer MP-EPA after management intervention (Table 2), but not in the buffer area around Ibity, which suggests an effect of the management measures carried out by the MBG on Ibity. In contrast, we observed for Itremo a marginally significant increase in number of ignitions. Despite the general decline in density of ignitions, there was no significant change in total burned area for the protected areas, except for the SCNP in Brazil, where a reduction in the annual total burned area was observed after management (Table 2). In the MP-EPA, mean and maximum burn scars sizes increased after management (Table 2).

Burn scar distribution: We observed a reduction in the number of scars and an increase in average area for Ibity and SCNP after management interventions (Fig. 3). This trend was weakly observable for their respective buffer areas, and completely absent for Itremo.

Fire season: The distribution of burned area across the fire season showed an increase in percent of burned areas towards the end of the season (October-November) after management interventions for Ibity and SCNP (Fig. 4). In contrast, we did not observe changes for the buffer area around Ibity, Itremo and MPEPA (Fig. 4). Comparing Ibity with its buffer area, we observed a

\section{Table 1}

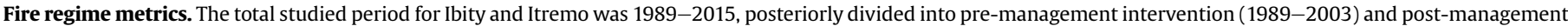

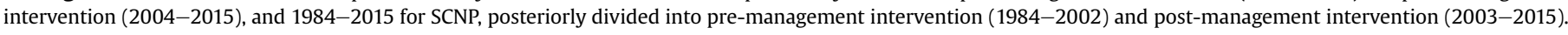

\begin{tabular}{ll}
\hline & Period \\
\hline Fire count & $1989-2015$ (Ibity and Itremo) \\
& $1984-2015$ (SCNP) \\
Time since last fire & $1989-2015$ (Ibity and Itremo) \\
& $1984-2015$ (SCNP) \\
Fire return period & $1989-2015$ (Ibity and Itremo) \\
& $1984-2015$ (SCNP) \\
& Pre- and post- management \\
& intervention for each park ${ }^{1}$
\end{tabular}

Measurement

Number of times individual pixels were burned during the study period, obtained by summing the binary raster maps of annual burned area (map of fire frequency for each protected area)

Maximum year value for each pixel after overlaying all annual raster maps, translating it into the number of elapsed years since the last fire from 2016 (Map of time elapsed since the last observed fire).

Median fire return interval (MEI; Moritz et al., 2009). From a random selection of 20.000 points (farther than $30 \mathrm{~m}$ apart) we extracted the exact dates of fire occurrence and used it to calculate the inter-fire intervals. The first and last fire observed for a pixel result in open-tailed intervals for which the exact fire return period is not known. A survival analysis was then run on the extracted data using the survReg package (Therneau, 2016) of R software, fitting a Weibull distribution with the shape parameter defining the hazard function, and the scale parameter the return period of fire. We then calculated the median fire return interval (MEI) and confidence intervals following Moritz et al. (2009):

$M E I=b \cdot\left(\log _{e}(2)\right)^{\frac{1}{c}}$

where $\mathrm{b}$ is the scale parameter and $\mathrm{c}$ is the shape parameter.

Fitting Weibull distributions is a standard method for reconstructing fire return intervals (Polakow and Dunne, 1999), which tend to be left-skewed, meaning that simply dividing the total number of years by the number of fires gives an over-estimation of the actual fire return period experienced by most parts of the landscape.

Total annual burned 1989-2015 (Ibity and Itremo) area $(\mathrm{km} 2$ and \%) 1984-2015 (SCNP)

Pre- and post- management intervention for each park ${ }^{1}$

Density of ignitions 1989-2015 (Ibity and Itremo) (ignitions $/ \mathrm{km}^{2}$ ) 1984-2015 (SCNP) Pre- and post- management intervention for each park ${ }^{1}$

Mean and maximum 1989-2015 (Ibity and Itremo) fire size 1984-2015 (SCNP) Pre- and post- management intervention for each park ${ }^{1}$

Fire season 1989-2015 (Ibity and Itremo) 1984-2015 (SCNP)

Pre- and post- management intervention for each park ${ }^{1}$

Fire scar distribution $1989-2015$ (Ibity and Itremo) 1984-2015 (SCNP)
Summed area of all burn scars mapped for each year, for each park, calculated from the annual burned area maps and expressed in $\mathrm{km} 2$ and percentage of total area.

Count of the total number of burn scars per year from the vector maps, and divided this number by the total area.

Mean and maximum sizes of burn scars per year from individual burn scar sizes.

Calculated by quantifying the percent of total burned area in each month during the fire season. Distribution of early and late fires.

Relationship between the number of scars against average scar area per year, to detect changes in the spatial configuration of fires across time. 


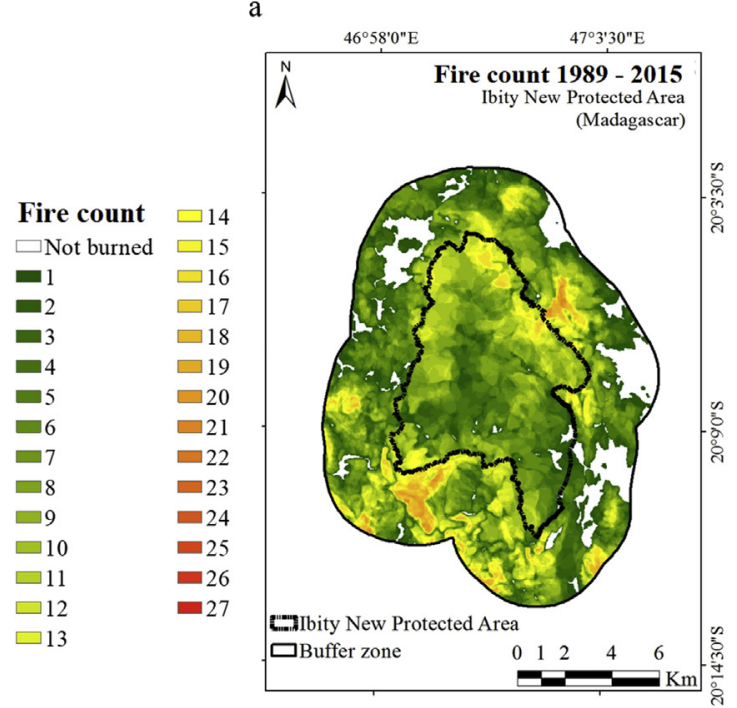

d

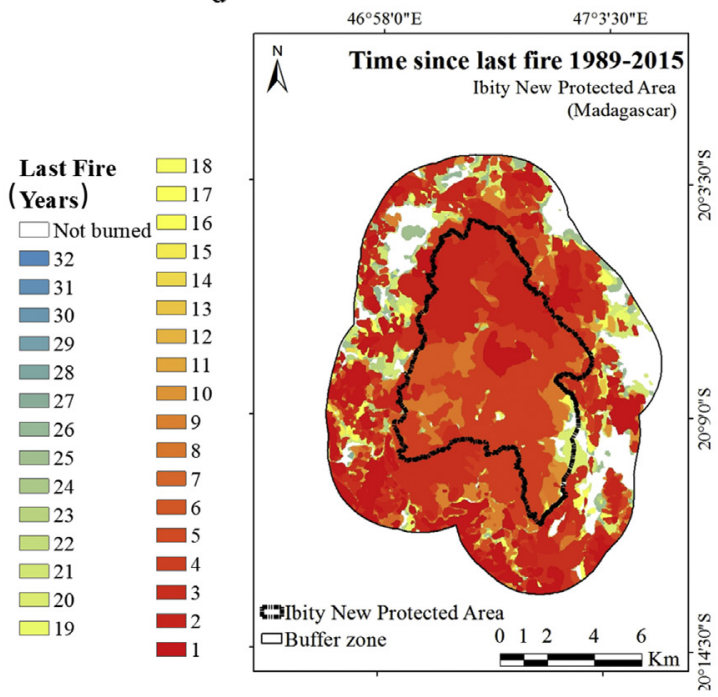

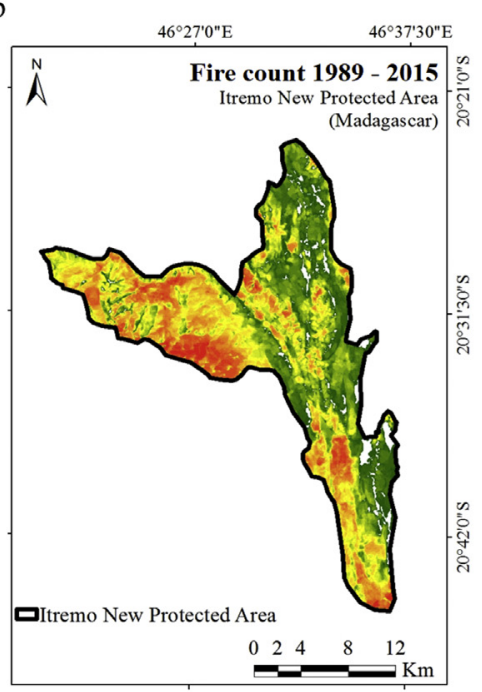

e

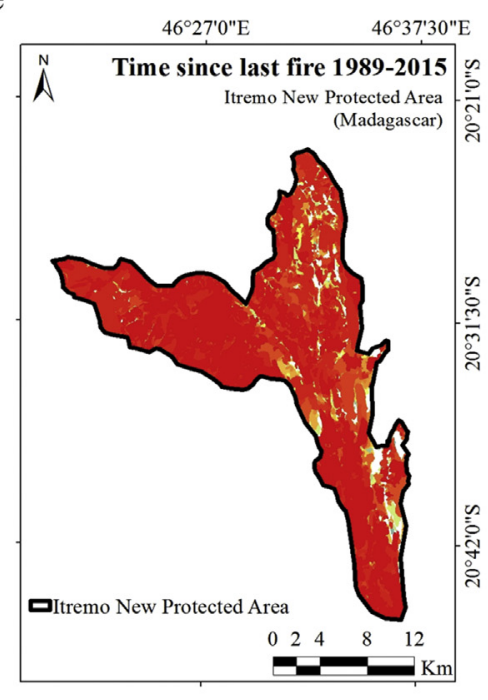

c

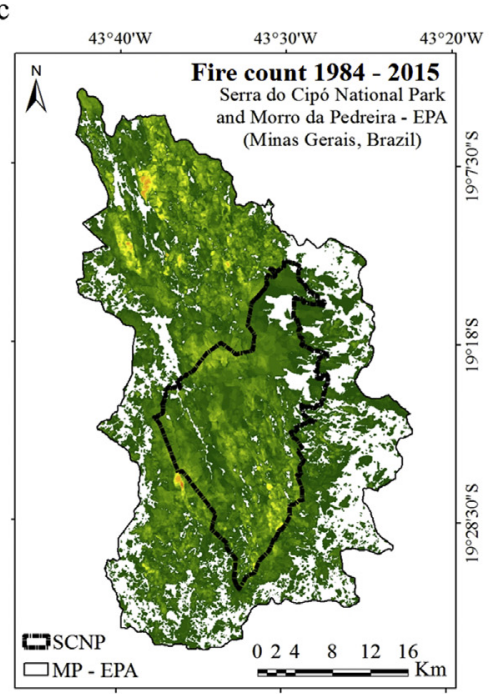

f

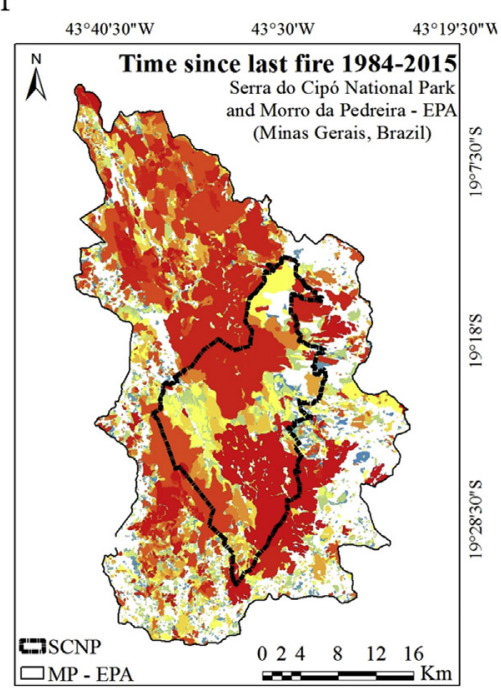

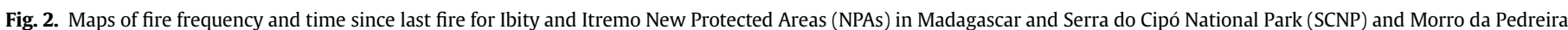
Protected Area (MP-EPA), in Brazil. Burned scars were mapped using Landsat TM, ETM+ and OLI images.

homogeneous distribution of burned areas within the park before management, while a marked peak was observed in October for the buffer. For Itremo, the peak of burned areas was in September, with a low percent of late fires between October and November. For SCNP and MP-EPA, the peak of fires was in September before management, which shifted to November after management intervention (Fig. 4).

Fire return interval: The median fire return interval (MEI) showed shorter return intervals for protected areas in Madagascar (3.23 years for Ibity and 1.82 years for Itremo) in contrast with Brazil (7.91 years for SCNP) (Table 1). We observed the shortest return intervals for Itremo, with a reduction after management intervention ( 2.02 vs. 1.86 years). The highest change was observed for the SCNP, where the MEI increased threefold after management (6.59-18.51 years), and MEI nearly doubled for buffer areas in both continents. Confidence intervals for return intervals before and after management did not overlap, suggesting a shift in fire regime after management intervention for these areas. The differences are also observable when comparing the histograms of frequency distribution for fire return intervals (Appendix S2.4).

\section{Discussion}

\subsection{Fire regime}

In comparison, the three parks represent a gradient of increasing occurrence of fire, from SCNP to Ibity to Itremo. It is also interesting to note that the parks under higher human influence suffered less burning after management interventions, while the opposite was observed for the remote Itremo. The strongly enforced fire suppression policy in Brazil (Durigan and Ratter, 2016) and the significant reduction in human activities on the SCNP (França and Ribeiro, 2008) have resulted, over 32 years, in longer fire return intervals, lower percentages of burned area and fewer ignitions, when compared with Malagasy parks. In contrast, despite a similar ban on fire in Madagascar (Kull, 2004), the lessmechanized, traditional ways employed by Malagasy people to manage agriculture and pasture using fire has resulted in shorter fire return intervals, a higher percentage of burned areas and a higher number of ignitions for Ibity and Itremo, suggesting that Madagascar's fire suppression policies are less effective. 
Table 2

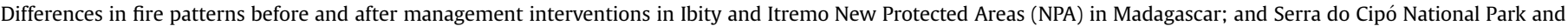

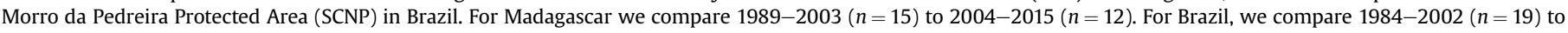
2003-2015 $(n=13)$.

\begin{tabular}{|c|c|c|c|c|c|c|}
\hline Fire regime metric & Area & Continent & Total $($ mean \pm se $)$ & Before (mean \pm se) & After $($ mean \pm se $)$ & p-value \\
\hline \multirow[t]{5}{*}{ Density of Ignitions (ignition $/ \mathrm{km}^{2}$ ) } & Ibity NPA & Africa & $0.21 \pm 0.04$ & $0.29 \pm 0.05$ & $0.12 \pm 0.02$ & 0.03 \\
\hline & Ibity Buffer & & $0.55 \pm 0.06$ & $0.6 \pm 0.11$ & $0.48 \pm 0.06$ & 0.64 \\
\hline & Itremo NPA & & $0.47 \pm 0.03$ & $0.42 \pm 0.04$ & $0.53 \pm 0.04$ & 0.06 \\
\hline & SCNP & South America & $0.27 \pm 0.04$ & $0.42 \pm 0.04$ & $0.04 \pm 0.01$ & $<0.001$ \\
\hline & MP-EPA & & $0.29 \pm 0.03$ & $0.37 \pm 0.04$ & $0.17 \pm 0.02$ & $<0.001$ \\
\hline \multirow[t]{5}{*}{ Total burned area $\left(\mathrm{km}^{2}\right.$ and \%) } & Ibity NPA & Africa & $\begin{array}{l}16.46 \pm 2.34 \\
(27.59 \pm 3.92)\end{array}$ & $\begin{array}{l}17.37 \pm 2.84 \\
(29.69 \pm 4.77)\end{array}$ & $\begin{array}{l}15.32 \pm 4.0 \\
(25.69 \pm 6.71)\end{array}$ & 0.37 \\
\hline & Ibity Buffer & & $\begin{array}{l}31.79 \pm 4.08 \\
(23.07 \pm 2.96)\end{array}$ & $\begin{array}{l}37.96 \pm 6.55 \\
(27.54 \pm 4.75)\end{array}$ & $\begin{array}{l}24.08 \pm 3.25 \\
(17.47 \pm 2.35)\end{array}$ & 0.14 \\
\hline & Itremo NPA & & $\begin{array}{l}154.54 \pm 8.14 \\
(42.86 \pm 2.26)\end{array}$ & $\begin{array}{l}146.59 \pm 10.39 \\
(40.66 \pm 2.88)\end{array}$ & $\begin{array}{l}164.47 \pm 12.83 \\
(45.62 \pm 3.56)\end{array}$ & 0.15 \\
\hline & SCNP & South America & $\begin{array}{l}36.79 \pm 5.39 \\
(11.56 \pm 1.71)\end{array}$ & $\begin{array}{l}46.88 \pm 7.03 \\
(14.79 \pm 2.23)\end{array}$ & $\begin{array}{l}22.05 \pm 6.77 \\
(6.85 \pm 2.12)\end{array}$ & 0.008 \\
\hline & MP-EPA & & $\begin{array}{l}82.09 \pm 7.39 \\
(8.16 \pm 0.74)\end{array}$ & $\begin{array}{l}86.75 \pm 10.1 \\
(8.63 \pm 1.01)\end{array}$ & $\begin{array}{l}75.28 \pm 10.82 \\
(7.46 \pm 1.1)\end{array}$ & 0.54 \\
\hline \multirow[t]{5}{*}{ Mean size of burned scars $\left(\mathrm{km}^{2}\right)$} & Ibity NPA & Africa & $1.81 \pm 0.32$ & $1.51 \pm 0.35$ & $2.19 \pm 0.57$ & 0.43 \\
\hline & Ibity Buffer & & $0.45 \pm 0.05$ & $0.51 \pm 0.08$ & $0.37 \pm 0.04$ & 0.26 \\
\hline & Itremo NPA & & $1.03 \pm 0.12$ & $1.11 \pm 0.19$ & $0.93 \pm 0.13$ & 0.18 \\
\hline & SCNP & South America & $1.13 \pm 0.31$ & $0.41 \pm 0.06$ & $2.19 \pm 0.67$ & 0.22 \\
\hline & MP-EPA & & $0.37 \pm 0.06$ & $0.26 \pm 0.04$ & $0.54 \pm 0.12$ & 0.004 \\
\hline \multirow[t]{5}{*}{ Max size of burned scars $\left(\mathrm{km}^{2}\right)$} & Ibity NPA & Africa & $6.81 \pm 1.28$ & $5.91 \pm 0.96$ & $7.94 \pm 2.66$ & 0.98 \\
\hline & Ibity Buffer & & $5.32 \pm 0.88$ & $5.66 \pm 1.37$ & $4.91 \pm 1.06$ & 0.72 \\
\hline & Itremo NPA & & $20.68 \pm 3.36$ & $21.57 \pm 5.32$ & $19.57 \pm 3.86$ & 0.76 \\
\hline & SCNP & South America & $9.95 \pm 2.25$ & $6.74 \pm 1.02$ & $14.66 \pm 5.18$ & 0.88 \\
\hline & MP-EPA & & $9.38 \pm 2.4$ & $4.23 \pm 0.55$ & $16.91 \pm 5.3$ & 0.007 \\
\hline \multirow{5}{*}{$\begin{array}{l}\text { Median fire return interval a } \\
\quad \text { (confidence intervals) }\end{array}$} & Ibity NPA & Africa & $3.23(3.21-2.34)$ & $3.15(3.13-3.16)$ & $3.65(3.63-3.67)$ & \\
\hline & Ibity Buffer & & $3.26(3.23-3.28)$ & $3.05(3.03-3.07)$ & $5.67(5.61-5.74)$ & \\
\hline & Itremo NPA & & $1.83(1.82-1.83)$ & $2.02(2.00-2.03)$ & $1.86(1.85-1.87)$ & \\
\hline & SCNP & South America & $7.91(7.85-7.97)$ & $6.59(6.53-6.65)$ & $18.51(18.13-18.91)$ & \\
\hline & MP-EPA & & $10.89(10.77-11.02)$ & $12.52(12.31-12.73)$ & $17.59(17.15-18.04)$ & \\
\hline
\end{tabular}

a Median fire return interval (MEI) and 95\% confidence intervals, calculated according to Moritz et al. (2009).

Despite the differences between countries, we observed a slightly higher percentage of burned area within the parks (SCNP and Ibity) in comparison with their buffer zones, where human population has probably fragmented the landscape and reduced the capacity of fire to spread. In the SCNP, livestock has been reduced since 2002 and completely banned since 2008 (França and Ribeiro, 2008), and controlled on Malagasy parks from 2003. Nevertheless, this activity is less controlled in both buffers areas.

In Brazil, livestock raising is allowed in the MP-EPA and people likely set fires to renew grasses for cattle. Moreover, the western side of the park receives a high influx of tourists and is permeated by access roads. As has been shown elsewhere (Andela and van der Werf, 2014), fragmentation by roads and other human activities can reduce the spread capacity of fire, resulting in increased fire return intervals and lower percentages of burned areas as we observed in this buffer area. Still, despite having smaller burned areas, there were more fire events observed on the western side of the park, probably associated with the higher levels of human activity and the lower percentage of woody vegetation in relation to the eastern region, making it more flammable (Alvarado et al., 2017).

The management history in Madagascar has neglected the conservation of savannas (with a reduced number of protected areas covering this vegetation type) in comparison with Brazil. In Madagascar highlands where Ibity and Itremo NPAs are located are dominated by a mosaic of rice fields, shrublands, woodlands, savannas, secondary grasslands and forest remnants (Du Puy and Moat, 1996). This region has a high level of human pressure and fire has been traditionally used as a tool for agriculture and livestock ranching (Kull, 1998). Thus, the shorter fire return intervals and the higher percentages of burned areas observed can be explained by high livestock activity in Madagascar Highlands, which have been historically burned every year to renew pastures for raising zebu (Kull, 1998); by the extended use of fire as a cheaper and faster way to clean rice fields after harvest at the end of the rainy season, or to eliminate pests (Kull, 2000); by the use of fire as a protesting method in the country, expressed as an increase in ignitions associated with historical politic crises (Kull, 2002a). Also, arson fires set by cattle thieves seeking to clear the evidence of their passage is common in Itremo, and cattle theft incidents are frequent due to its remote location and position among routes for cattle migration from the south (Toliara region) to the center of the country (Antananarivo) (C. Birkinshaw, Per. Com). In contrast with the suggested by Alvarado et al. (2014), Itremo had the highest percentage of burned area and ignitions. This protected area is located in a remote massif and has low human density around the park (Birkinshaw et al., 2004). The reduced number of human settlements around Itremo and the prevalence of savanna vegetation dominated by few Poaceae species forming a continuous layer probably resulted in faster and larger fire spreads, as they are not controlled by managers or local people (C. Lehmann, Pers. Com). Our results thus suggest an effect of population density around the parks on total burned area in both continents, as has been demonstrated in Africa where increases in population density have resulted in a decrease of burned areas (Archibald et al., 2009).

\subsection{Changes in fire patterns after management intervention}

Our results show for the Malagasy sites that, as shown for other African savannas, burned area did not respond to management, but number of fires, fire season, fire size distribution, and fire return interval have all changed (Archibald, 2016; Van Wilgen et al., 2004).

\subsubsection{Burned area, fire size and number of fires}

We expected that reduction in ignitions after management 

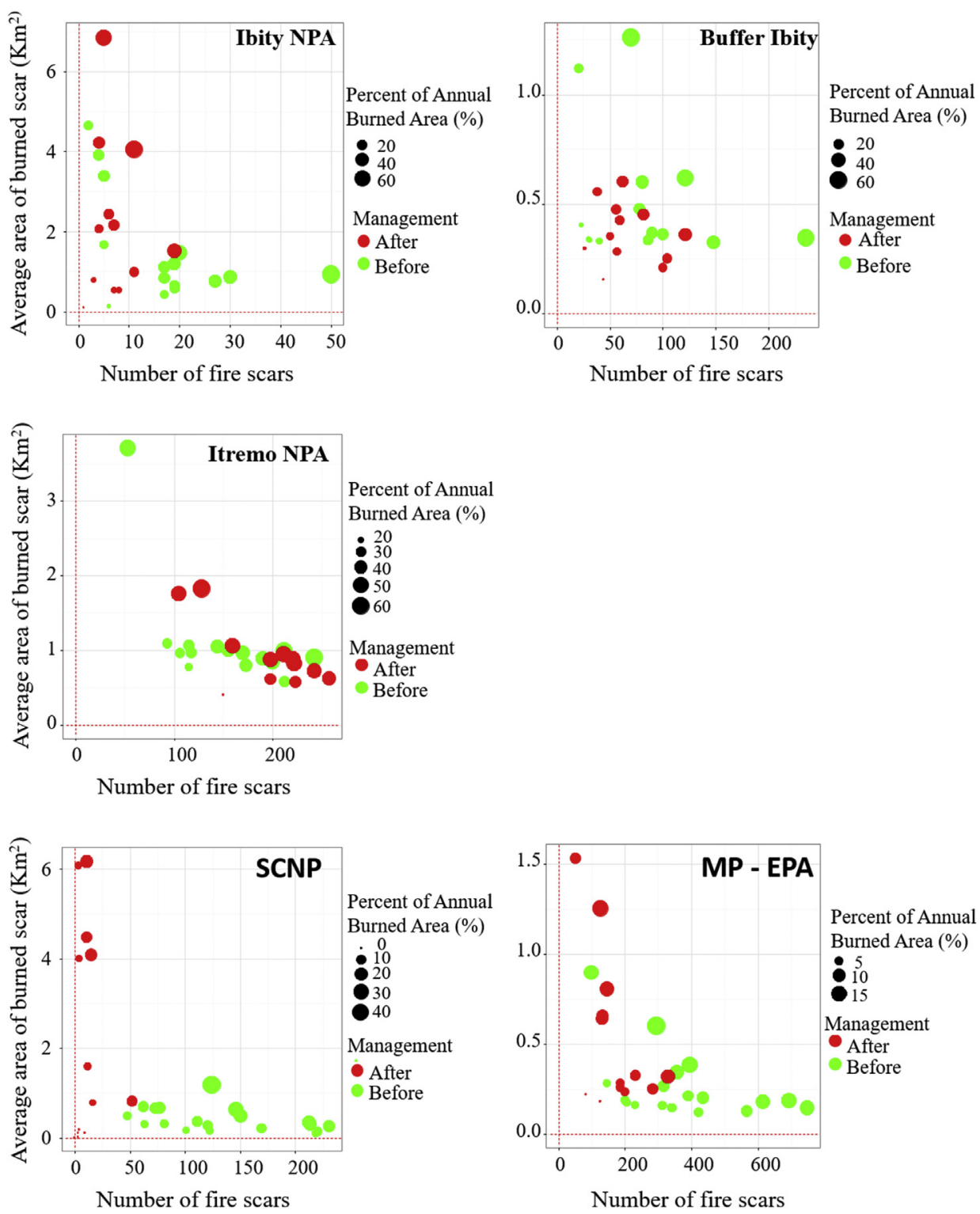

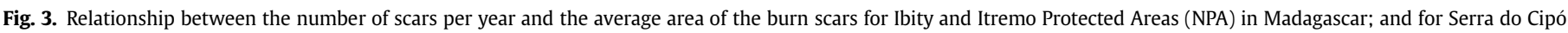
National Park and Morro da Pedreira Protected Area (SCNP and MP-EPA) in Brazil.

intervention would reduce total burned area. However, we observed a decrease in the number of fires with an increase of larger scar sizes, which kept total burned area unchanged. Fire management by farmers prior to intervention possibly created a mosaic of burned and unburned areas, and a dynamic of different regeneration times (Laris, 2002; Mistry et al., 2005). After human and livestock exclusion, accumulation of grass fuel load may have increased, leading to potentially larger fires and associated burn scars. These large fires can affect vegetation negatively by changing the tree-grass balance (Smit et al., 2016), and impact human populations by spreading to settlements and causing human and economic losses (Johnston, 2009). Large fires are often more difficult to control and thus can cause more damages for nature and humans (Yates et al., 2008).

For some agroecosystems, patches of burned areas may work as firebreaks, reducing available fuel biomass and limiting fire spread (Andela and van der Werf, 2014). In fact, in African conservation areas where fire effects are better known, prescribed burning is used to conserve biodiversity and maximize the benefits of a diverse fire regime (Brockett et al., 2001). This prescribed burning system allows control of burned area per year, accumulation of grass fuel load, and the number of fires per year is a function of the percentage of area burnt, reducing the effects of extended and severe fires. Future studies of the ecological outcomes of various fire regimes (natural, human unintentional, and human prescribed) are needed to better define the appropriate management approach to fire as a conservation tool. Several studies of experimental prescribed fires are carried out in other protected areas in Brazil and could be used as a baseline for future works to define the desired fire regime in studied protected areas (e.g. Fidelis et al., 2010; Rissi et al., 2017, and the integrated fire management plan carried out on the ESEC Serra Geral do Tocantins, C. Barrantes, ICMBio, Pers. Com).

\subsubsection{Fire season}

The increase in late fires after management in the SCNP and Ibity is alarming. According to Archibald (2016) and Laris (2002), late season fires are more common where fire is banned or illegal, as is the case in Brazil and Madagascar and as observed for our studied 

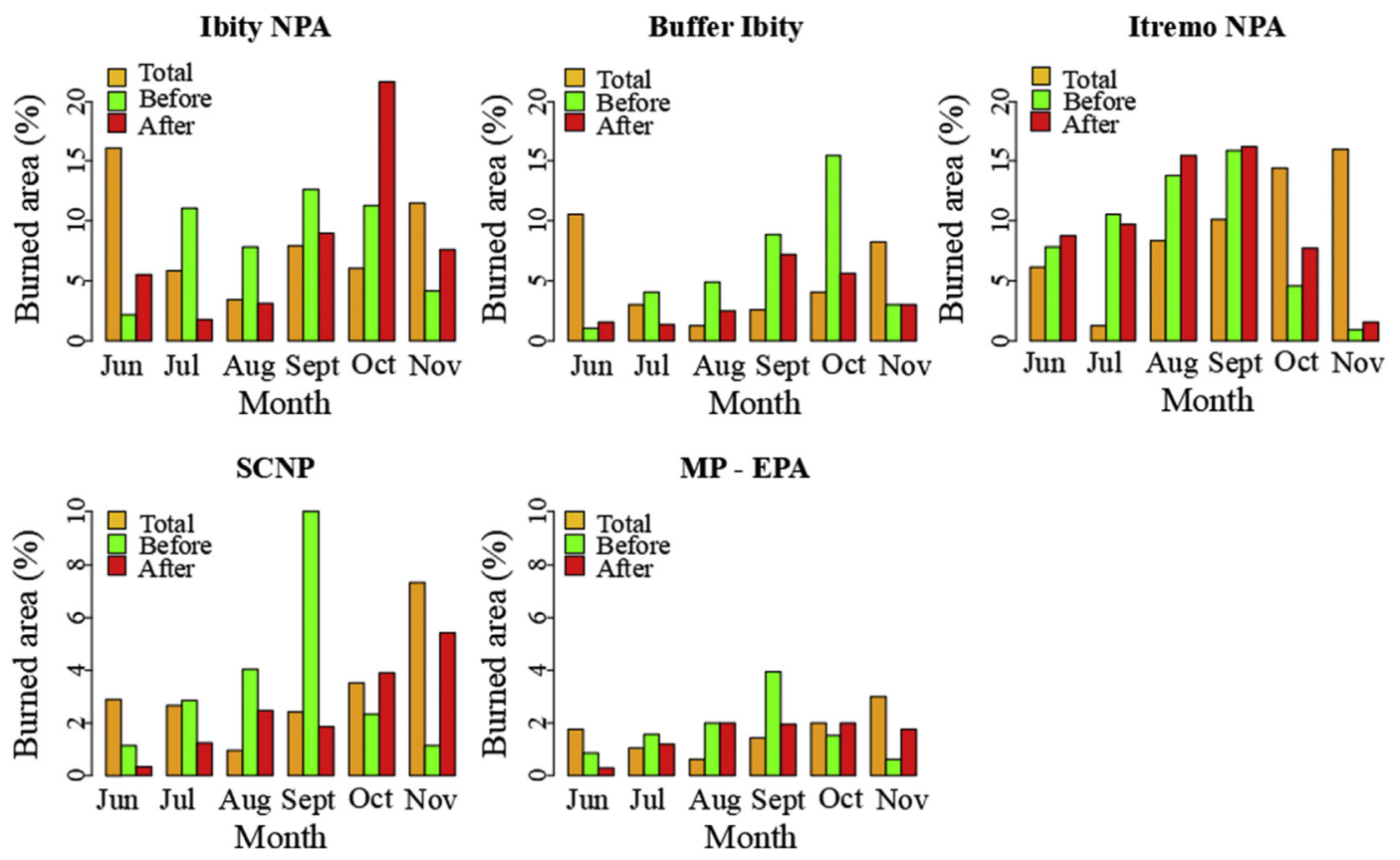

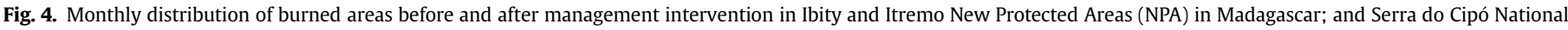

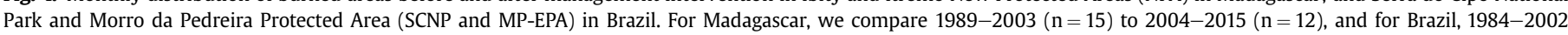
$(\mathrm{n}=19)$ to $2003-2015(\mathrm{n}=13)$.

areas. This change can be caused by increased fuel loads from lack of human ignitions earlier in the season. Early dry-season fires tend to be small because fuels have not yet fully cured, while late season fires are hotter and larger (Brockett et al., 2001), as fire intensity increases over the dry season due to decreases in relative humidity and increases in wind speed and temperature (Archibald et al., 2010; Govender et al., 2006; Williams et al., 1998). Furthermore, changes in fire seasonality may affect plant phenology, favoring or preventing some species from flowering or fruiting after fire.

\subsubsection{Fire return interval}

Changes in fire return intervals were more drastic in the SCNP than in Ibity and Itremo. Return intervals can be extended in areas with higher human densities, but in our case, it seems that fire intervals responded directly to fire suppression policies after management interventions, particularly in Brazil. With the reduction of livestock in the park, the number of fires set by people to renew pastures also decreased. In Madagascar, fire return intervals were less affected by fire suppression policies, as traditional use of fire by people hinders control of human fire-setting. In both cases, the change in return intervals is consistent with a decrease in ignitions and lower fire frequencies. If fire suppression policies are the cause for extending fire return intervals, prolonged use of such practices could lead to woody encroachment (Hoffmann, 1999), working against the intended conservation targets.

\section{Conclusion}

We have shown how fire suppression policies at national and local levels have changed fire regimes in Malagasy and Brazilian protected areas. We found 1 ) a reduction in the number of ignitions across time in each continent but no significant change in total burned area, with a higher fire frequency in Madagascar's parks; and 2) after management intervention measures fire regime was modified with changes in the burn scar size distribution, longer fire return periods and a seasonal shift in burning towards later fires.
Our inter-continental comparison has highlighted the impact of differences in law enforcement; although both countries ban fire, suppression is far more effective in Brazil than in Madagascar. Still, over $90 \%$ of the area of all parks were burned during the study period, and fire suppression is clearly not appropriate for these grassy tropical ecosystems. Instead, management policies including prescribed fires would be more successful in achieving the desired conservation outcomes. The effects of changes in fire patterns on ecosystem function should be better studied in these areas to determine if the increase in large fires and fire intervals has a positive or negative impact on vegetation.

\section{Acknowledgments}

S.T. Alvarado received postdoctoral support from grants \#2014/ 12728-1 and \#2016/00879-0, São Paulo Research Foundation (FAPESP). This research was also supported by FAPESP - Microsoft Research Foundation grant \#2013/50155-0. T.S.F. Silva received support from a research productivity grant from the National Council for Scientific and Technological Development (CNPq, grant \#310144/2015-9). We are grateful to Dr. Chris Birkinshaw and Mamisoa Andrianjafy, from the Missouri Botanical Garden in Madagascar, for providing the final delimitation and management information data for Ibity NPA, and to Dr. Caroline Lehmann for comments and information about the management and context of Itremo NPA.

\section{Appendix A. Supplementary data}

Supplementary data related to this article can be found at https://doi.org/10.1016/j.jenvman.2018.04.004.

\section{References}

Alvarado, S.T., Buisson, E., Carrière, S.M., Rabarison, H., Rajeriarison, C., Andrianjafy, M., Randriatsivery, F.M., Rasoafaranaivo, M.H., Raharimampionona, J., Lowry II, P.P., Birkinshaw, C., 2015. Achieving sustainable 
conservation in Madagascar: the case of the newly established Ibity Mountain Protected Area. Trop. Conserv. Sci. 8, 367-395.

Alvarado, S.T., Buisson, E., Rabarison, H., Rajeriarison, C., Birkinshaw, C., Lowry II, P.P. 2014. Comparison of plant communities on the Ibity and Itremo massifs, Madagascar, with contrasting conservation histories and current status. Plant Ecol. Divers 7, 497-508. https://doi.org/10.1080/17550874.2013.804131.

Alvarado, S.T., Fornazari, T., Cóstola, A., Morellato, L.P.C., Silva, T.S.F., 2017. Drivers of fire occurrence in a mountainous Brazilian cerrado savanna: tracking long term fire regimes using remote sensing. Ecol. Indic. 78, 270-281. https://doi.org/10. 1016/j.ecolind.2017.02.037.

Andela, N., van der Werf, G.R., 2014. Recent trends in African fires driven by cropland expansion and El Niño to La Niña transition. Nat. Clim. Chang. 4, 791-795. https://doi.org/10.1038/nclimate2313.

Andersen, A.N., Braithwaite, R.W., Cook, G.D., Corbett, L.K., Williams, R.J., Douglas, M.M., Gill, A.M., Setterfield, S.A., Muller, W.J., 1998. Fire research for conservation management in tropical savannas: introducing the Kapalga fire experiment. Aust. J. Ecol. 23, 95-110. https://doi.org/10.1111/j.1442-9993.1998. tb00708.x.

Archibald, S., 2016. Managing the human component of fire regimes: lessons from Africa. Philos. Trans, R. Soc. Lond. B Biol. Sci. 371.

Archibald, S., Nickless, A., Govender, N., Scholes, R.J., Lehsten, V., 2010. Climate and the inter-annual variability of fire in southern Africa: a meta-analysis using long-term field data and satellite-derived burnt area data. Glob. Ecol. Biogeogr. 19, 794-809.

Archibald, S., Roy, D.P.D., Wilgen, V., Brian, W., Scholes, R.J., 2009. What limits fire? An examination of drivers of burnt area in Southern Africa. Glob. Change Biol 15, 613-630.

Archibald, S., Staver, A.C., Levin, S.A., 2012. Evolution of human-driven fire regimes in Africa. Proc. Natl. Acad. Sci. 109, 847-852.

Baker, W.L., Shinneman, D.J., 2004. Fire and restoration of pi\ non-juniper woodlands in the western United States: a review. For. Ecol. Manage. 189, 1-21.

Birkinshaw, C., Andriamihajarivo, T.H., Rakotoarinivo, C.R., Randrianaina, L., Randrianarivelo, C., Rasamimanana, V.N., Rasolondraibe, B., Ravoahangy, A., Razafindrasoa, R., Seing, S.T., 2006. Le massif d'Ibity: Description, évaluation et stratégie de conservation. Unpublished Report. Missouri Botanical Garden, Madagascar Program., Antananarivo, Madagascar.

Birkinshaw, C., Andriamihajarivo, T.H., Randrianaina, L., Randrianarivelo, C., Rasolondraibe, B., Ravohangy, A., Razafindrasoa, R., 2004. Evaluation bioécologique des ressources naturelles et pressions anthropiques - études socioéconomiques en vue d'établir une proposition de stratégie de conservation pour le Massif d'Itremo. Missouri Botanical Garden, Madagascar Program., Antananarivo, Madagascar.

Bond, W.J., Woodward, F.I., Midgley, G.F., 2005. The global distribution of ecosystems in a world without fire. New Phytol. 165, 525-538.

Bowman, D.M.J.S., Balch, J., Artaxo, P., Bond, W.J., Cochrane, M.A., D'Antonio, C.M. DeFries, R., Johnston, F.H., Keeley, J.E., Krawchuk, M.A., Kull, C.A., Mack, M. Moritz, M.A., Pyne, S., Roos, C.I., Scott, A.C., Sodhi, N.S., Swetnam, T.W., 2011. The human dimension of fire regimes on Earth. J. Biogeogr. 38, 2223-2236. https:/ doi.org/10.1111/j.1365-2699.2011.02595.x.

Brockett, B.H., Biggs, H.C., van Wilgen, B.W., 2001. A patch mosaic burning system for conservation areas in southern African savannas. Int. J. Wildl. Fire. 10, 169-183. https://doi.org/10.1071/WF01024.

Crawley, M.J., 2011. Statistics: an Introduction Using R. John Wiley \& Sons Ltd.

Du Puy, D.J., Moat, J., 1996. A Refined Classification of the Primary Vegetation of Madagascar Based on the Underlying Geology: Using GIS to Map its Distribution and to Assess its Conservation Status. ORSTOM, Paris, pp. 205-218. Biogeogr. Madagascar.

Durigan, G., Ratter, J.A., 2016. The need for a consistent fire policy for Cerrado conservation. J. Appl. Ecol. 53, 11-15. https://doi.org/10.1111/1365-2664.12559.

Fidelis, A., Delgado-Cartay, M.D., Blanco, C.C., Müller, S.C., Pillar, V.D., Pfadenhauer, J. 2010. Fire intensity and severity in Brazilian Campos grasslands. Interciencia 35 $739-745$.

França, H., Ribeiro, K.T., 2008. Mapeamento de queimadas no Parque Nacional da Serra do Cipó e na Área de Proteção Ambiental Morro da Pedreira, MG: 1984 2007. Jaboticatubas, MG.

Govender, N., Trollope, W.S.W., Van Wilgen, B.W., 2006. The effect of fire season, fire frequency, rainfall and management on fire intensity in savanna vegetation in South Africa. J. Appl. Ecol. 43, 748-758. https://doi.org/10.1111/j.1365-2664 2006.01184.x.

Hantson, S., Pueyo, S., Chuvieco, E., 2015. Global fire size distribution is driven by human impact and climate. Glob. Ecol. Biogeogr. 24, 77-86. https://doi.org/10 $1111 /$ geb.12246.

Higgins, S.I., Bond, W.J., February, E.C., Bronn, A., Euston-Brown, D.I.W., Enslin, B., Govender, N., Rademan, L., O'Regan, S., Potgieter, A.L.F., Scheiter, S., Sowry, R., Trollope, L., Trollope, W.S.W., 2007. Effects of four decades of fire manipulation on woody vegetation structure in savanna. Ecology 88, 1119-1125.

Hoffmann, W.A., 1999. Fire and population dynamics of woody plants in a neotropical savanna: matrix model projections. Ecology 80,1354-1369. https:// doi.org/10.1890/0012-9658(1999)080[1354:FAPDOW]2.0.CO;2.

Hoffmann, W.A., Jaconis, S.Y., Mckinley, K.L., Geiger, E.L., Gotsch, S.G., Franco, A.C. 2012. Fuels or microclimate? Understanding the drivers of fire feedbacks at savanna-forest boundaries. Austral Ecol. 37, 634-643. https://doi.org/10.1111/j. 1442-9993.2011.02324.x

IBGE, 2010. Censo Demográfico - 2010. IBGE, Rio de Janeiro [WWW Document]. Inst. Bras. Geogr. e Estatística - IBGE. URL. http://mapasinterativos.ibge.gov.br/ grade/default.html. (Accessed 21 February 2017).

Johnston, F., 2009. Bushfires and human health in a changing environment. Aust. Fam. Physician 38, 720-725.

KEW, 2012. Itremo Massif Protected Area Project. Royal Botanical Garden KEW [WWW Document]. URL. http://www.kew.org/science-research-data/directory/ projects/Itremo-Massif-Protected-Area-Project.htm.

Kull, C.A., 2004. Isle of Fire: the Political Ecology of Landscape Burning in Madagascar. University Of Chicago Press.

Kull, C.A., 2002a. Madagascar aflame: landscape burning as peasant protest, resistance, or a resource management tool? Polit. Geogr. 21, 927-953.

Kull, C.A., 2002b. The "degraded" tapia woodlands of highland Madagascar: rural economy, fire ecology, and forest conservation. J. Cult. Geogr. 19, 95-128.

Kull, C.A., 2000. Deforestation, erosion, and fire: degradation myths in the environmental history of Madagascar. Environ. Hist. Camb. 6, 423-450.

Kull, C.A., 1998. Leimavo revisited: agrarian land-use change in the highlands of Madagascar. Prof. Geogr. 50, 163-176.

Laris, P., 2002. Burning the seasonal mosaic: preventative burning strategies in the wooded savanna of southern Mali. Hum. Ecol. 30, 155-186.

Laris, P., Wardell, D.A., 2006. Good, bad or "necessary evil"? Reinterpreting the colonial burning experiments in the savanna landscapes of West Africa. Geogr. J. 172, 271-290.

Le Page, Y., Oom, D., Silva, J.M.N., Jönsson, P., Pereira, J.M.C., 2010. Seasonality of vegetation fires as modified by human action: observing the deviation from eco-climatic fire regimes. Glob. Ecol. Biogeogr. 19, 575-588. https://doi.org/10. 1111/j.1466-8238.2010.00525.x.

Le Stradic, S., Buisson, E., Fernandes, G.W., 2014. Restoration of Neotropical grasslands degraded by quarrying using hay transfer. Appl. Veg. Sci. 17, 482-492. https://doi.org/10.1111/avsc.12074.

Miranda, H.S., Sato, M.N., Neto, W.N., Aires, F.S., 2009. Fires in the cerrado, the Brazilian savanna. In: Springer Praxis Books. Springer, Berlin Heidelberg, pp. 427-450.

Mistry, J., 1998. Fire in the cerrado (savannas) of Brazil: an ecological review. Prog. Phys. Geogr. 22, 425-448. https://doi.org/10.1177/030913339802200401.

Mistry, J., Berardi, A., Andrade, V., Krahô, T., Krahô, P., Leonardos, O., 2005. Indigenous fire management in the cerrado of Brazil: the case of the Krahô of Tocantíns. Hum. Ecol. 33, 365-386. https://doi.org/10.1007/s10745-005-4143-8.

Moritz, M.A., Moody, T.J., Miles, L.J., Smith, M.M., de Valpine, P., 2009. The fire frequency analysis branch of the pyrostatistics tree: sampling decisions and censoring in fire interval data. Environ. Ecol. Stat. 16, 271-289. https://doi.org/ 10.1007/s10651-007-0088-y.

Negreiros, D., Fernandes, G.W., Berbara, R.L.L., Rodarte, L.H.O., Pimentel de Ulhôa Barbosa, N., 2011. Caracterização físico-química de solos quartzíticos degradados e áreas adjacentes de campo rupestre na Serra do Cipó, MG, Brasil. Neotrop. Biol. Conserv. 6, 156-161.

Polakow, D.A., Dunne, T.T., 1999. Modelling fire-return interval T: stochasticity and censoring in the two-parameter Weibull model. Ecol. Modell. 121, 79-102. https://doi.org/10.1016/S0304-3800(99)00074-5.

Price, O.F., Pausas, J.G., Govender, N., Flannigan, M., Fernandes, P.M., Brooks, M.L., Bird, R.B., 2015. Global patterns in fire leverage: the response of annual area burnt to previous fire. Int. J. Wildl. Fire. 24, 297-306. https://doi.org/10.1071/ WF14034.

R Core Team, 2016. R: a Language and Environment for Statistical Computing. R Foundation for Statistical Computing.

Ramos-Neto, M.B., Pivello, V.R., 2000. Lightning fires in a Brazilian savanna national park: rethinking management strategies. Environ. Manage. 26, 675-684. https://doi.org/10.1007/s002670010124.

Rissi, M.N., Baeza, M.J., Gorgone-Barbosa, E., Zupo, T., Fidelis, A., 2017. Does season affect fire behaviour in the Cerrado? Int. J. Wildl. Fire. 26, 427-433. https://doi. org/10.1071/WF14210.

Smit, I.P.J., Asner, G.P., Govender, N., Vaughn, N.R., van Wilgen, B.W., 2016. An examination of the potential efficacy of high-intensity fires for reversing woody encroachment in savannas. J. Appl. Ecol. 53, 1623-1633. https://doi.org/10.1111/ 1365-2664.12738.

Therneau, T.M., 2016. https://cran.r-project.org/web/packages/survival/index.html [accessed January. 25, 2016]

Van Wilgen, B.W., Govender, N., Biggs, H.C., Ntsala, D., Funda, X.N., 2004. Response of savanna fire regimes to changing fire-management policies in a large African national park. Conserv. Biol. 18, 1533-1540. https://doi.org/10.1111/j.1523-1739. 2004.00362.x.

Williams, R., Gill, A., Moore, P., 1998. Seasonal changes in fire behaviour in a tropical savanna in northern Australia. Int. J. Wildl. Fire. 8, 227-239. https://doi.org/10. 1071/WF9980227.

Yates, C.P., Edwards, A.C., Russell-Smith, J., 2008. Big fires and their ecological impacts in Australian savannas: size and frequency matters. Int. J. Wildl. Fire. 17, 768-781. https://doi.org/10.1071/WF07150.

Zhu, Z., Wang, S., Woodcock, C.E., 2015. Improvement and expansion of the Fmask algorithm: cloud, cloud shadow, and snow detection for Landsats 4-7, 8, and Sentinel 2 images. Remote Sens. Environ. 159, 269-277. https://doi.org/10.1016/ j.rse.2014.12.014. 